\title{
Lucien Sfez e a tecnologia vista como narrativa.
}

\author{
Entrevista concedida ao prof. Dr. Álvaro Nunes \\ Larangeira, docente do Mestrado em Comunicação \\ e Linguagens, do Programa de Pós-graduação da \\ Universidade Tuiuti do Paraná, e um dos líderes do \\ grupo de pesquisa JORXXI. \\ E-mail: larangeira@terra.com.br
}

Lucien Sfez passou o segundo semestre de 2007 no Brasil, percorreu dez estados e foi acolhido em uma quinzena de programas de pós-graduação em Comunicação. Nas palestras, seminários, módulos e cursos abordou as estratégias da comunicação para ocupar os interstícios deixados pelas megaideologias, listou as manifestações das tecnologias do espírito na comunicação confusional, diagnosticou o tautismo oriundo da fusão entre a tautologia e o autismo e biografou a nova utopia do século XXI: a grande saúde, temáticas com as quais o professor emérito da Universidade de Paris I - Panthéon-Sorbonne tornou-se referência na área da comunicação. A estas, acrescentou outra idéia: a tecnologia é uma narrativa. Ficcional? Mega, macro, meso, microrrelato? Adiante teremos a resposta.

\section{O substrato epistemológico da comunicação}

Por enquanto, conheçamos a base da obra do editor da Revista Quaderni da Paris 1, coordenador do Departamento de Estudos em Comunicação, Tecnologia e Poder (DEA) e, no período 1997/2005, diretor da Escola Doutoral de Ciência Política da Sorbonne. Para ele, a comunicação forja-se no núcleo epistemológico do qual se configura a forma simbólica. Saberes em profusão de múltiplas áreas - como ciência política, sociologia, história, filosofia, psicologia, direito, medicina, biologia, administração, ciências da informação, computação, inteligência artificial e tantas outras - circulam pela noosfera da comunicação e são reelaborados para gerar a imagem do campo comunicacional. Este, imbuído da missão de encontrar em si mesmo a pedra filosofal com a qual alcançará o idolatrado estatuto da ciência, gira sobre o próprio eixo e, pela forma do fluxo contínuo, representa-se como uma nova utopia com a mesma ambição daquelas doutrora. Sfez esmerilha o substrato epistemológico da comunicação e as formas de representação e expressão a partir da divisão do objeto em pelo menos três formas: representativa, expressiva e confusional.

\section{0 tautismo das tecnologias do espírito}

A comunicação confusional materializa-se quando a comunicação representativa, cuja metáfora é a máquina, e a comunicação expressiva, simbolizada pelo organismo, confundem-se. Uma se toma pela outra. Impera uma nova razão sustentada pelo quadrilátero constituinte das tecnologias do espírito: a rede, o paradoxo, a simula- ção e a interação. A rede é formada pelo entrelaçamento dos canais, cabos, satélites, fibras óticas, tecnologias móveis. É a circulação permanente em movimentos circulares, autistas. O paradoxo corporaliza-se pelo " $\mathrm{e}$ " e a relatividade generalizada. O paradoxalismo alcança o patamar da não-contradição e sistematiza-se pela autorepresentação e auto-referência. A simulação prefigura o mundo desontologizado, solto, sem raízes e limites. E no entrelaçamento da rede com o paradoxo e com a simulação, a interação cirze o círculo e o argumento sincrônico das tecnologias do espírito.

Tecnologias, cabe recordar, cujas artérias são abastecidas pelo tautismo, a forma simbólica da comunicação. O tautismo, limado pela contração da tautologia com o autismo, apodera-se da totalidade do primeiro e do autoencerramento do segundo. Considera-se a expressão do mundo, embora seja apenas uma representação. Tomase como realidade porque assim se enxerga no espelho. Encontra-se no lugar do sujeito e do objeto. Num cenário baudrillardiano, é o homem em frente da televisão sem imagem. É a televisão à frente do homem e é, também, a falta da imagem no aparelho. Unifica a realidade pelo jogo de espelhos e apodera-se do mundo como se o mundo fosse por ele originado. $\mathrm{O}$ tautismo empresta-se à máquina porque da máquina se recebe. Dá a alma a deus para deus achar-se o criador da alma. Comprovase pela repetição tautológica e pela surdez autista. Sfez exemplifica: "Tenho a ilusão de estar ali, de ser aquilo, quando na verdade o que há são decupagens e escolhas prévias a meu olhar. A tal ponto que acabo emprestando à máquina social, televisiva ou informática, minhas próprias faculdades. Tendo-as delegado a ela, elas retornam a mim como se sua origem estivesse alhures, no céu tecnológico" (2007, p. 108).

\section{Da saúde perfeita como utopia do século XXI}

Céu onde se vislumbra a saúde perfeita. Para compreendê-la como o novo projeto mundial convém listarmos os cinco fundamentos nos quais se baseia. Quinteto, aliás, alicerçador do imaginário da modernidade: "A utopia de um registro total; o fazer um ser à nossa imagem, como homem é à de deus, graças à ciência, indiscutível, transparente, luminosa como um gládio sagrado; a crença na onipotência de uma ciência eletrônica; a ilusão da liberdade; e a criação de uma máquina perfeita" (Sfez, 1996). Por falar em perfeição, eis a gênese da saúde perfeita: o ser novo, liberto do envelhecimento, da morte.

Sfez pesquisa há 30 anos a gestação da nova eco-bioreligião da humanidade. Participou e acompanhou nos Estados Unidos, na Europa e no Japão os projetos Genoma, Biosfera II e Vida Artificial. O primeiro, executado por um consórcio internacional, propunha-se a mapear até 2025 todos os genes humanos e, assim, diagnosticar 
aqueles responsáveis por determinadas doenças. O segundo, concebido nos Estados Unidos, consistiu em colocar em imensos hangares de vidros, erguidos numa área batizada como Oracle, em Tucson, no deserto do Arizona, quatro homens e quatro mulheres, 3.800 espécies animais e vegetais e simulações dos cinco principais biomas do planeta Terra. Lá ficaram durante dois anos - setembro de 1991 a setembro de 1993 - monitorados por dois mil sensores eletrônicos e assistidos por 600 mil pagantes (aqui está a inspiração para os mentores do programa televisivo Big Brother).

O terceiro, o Artificial Life, projetado por cientistas do Instituto Santa Fé, no Novo México, preconizava originar no computador seres virtuais capazes de realizar as mesmas funções humanas.

Qual o traço comum entre os três? O aperfeiçoamento obsessivo, a assepsia obstinada, a vida imaculada. A saúde perfeita, em suma. O descobrimento das possíveis fontes da imperfeição e desequilíbrio para a cura a priori - se necessário, extirpar para evitar males futuros, como Sfez presenciou nos Estados Unidos quando uma amiga retirou os ovários saudáveis, e por pouco não fez o mesmo com as mamas, porque a mãe e a tia haviam sofrido tumores ovarianos. É preciso medicar o desvio, encontrar o inimigo, o qual se pode encontrar no exterior, sob a forma do elemento corrosivo da camada de ozônio, ou no interior do próprio corpo, disfarçado como colesterol ou açúcar. O poder emanado pela saúde perfeita engloba a retórica da comunicação. Absorve-a. "É incomparável a força da grande saúde cotejada com a retórica da comunicação, tanto no aspecto da purificação do corpo, e desta forma devolver o ser humano ao estágio do Adão anterior ao pecado, o Adão puro, original, quanto na extensão planetária com o fim dos agentes poluentes, das idéias conflitantes, do fim de quaisquer ruídos comunicacionais", justifica Sfez. A saúde perfeita, então, apresenta-se como o todo do planeta e da vida. Efeito autista, retroalimentação espiritual.

\section{A conversa}

E a técnica e a tecnologia nisso tudo? Pois elas estão presentes nos postulados da utopia da saúde perfeita. É a providência inerente a toda narrativa ou projeto utópico. "A técnica sempre foi solicitada pelas utopias, como o Deus ex machina que torna possível dispositivos singulares... A utilização da técnica assegura, pois, ao relato a possibilidade de transformações imediatas, é a mola indispensável ao andamento da narrativa." (1996, p. 109-110). Então a tecnologia, como discurso da técnica, é uma narrativa? Ficcionista? Micro, meso, macro, meganarrativa? Pois quem responde é o próprio Lucien Sfez, nesta entrevista concedida em Porto Alegre, 17 de dezembro, mesmo dia do retorno a Paris.

ÁLVARO LARANGEIRA - A tecnologia é uma narrativa?

LUCIEN SFEZ - A tecnologia é uma narrativa, sim, porque em primeiro lugar é preciso distinguir a técnica da tecnologia. A técnica é uma série de objetos técnicos, que têm uma história, uma filiação entre eles e que têm todo um processo de desenvolvimento. São realidades concretas. A tecnologia não é nada disso. Como diz a etimologia, a tecnologia é um discurso sobre a técnica. É um discurso que existe para carregar a técnica, dar-lhe sustentação, para apresentar um futuro glorioso para a técnica, ou detestável. A gente conhece bem autores que contam as histórias sobre a técnica. Negroponte e as equipes do MIT, Pierre Lévy, que contam todas essas extravagâncias. Então há esses, como Negroponte e Lévy, que dizem que a técnica leva o homem em direção a um futuro glorioso, ou então ao contrário, como Virilio, para quem a técnica carrega o homem na direção do nada. Fico a pensar que o Virilio chegou a escrever um livro chamado Bomba Informática, em que a informática causaria tantos estragos quanto a bomba atômica. São coisas que me deixam perplexo. A tecnologia é um discurso feito a respeito da técnica, como se os objetos técnicos não tivessem condições de se sustentar por si mesmos, por sua utilidade.

\section{Desde o começo da humanidade sonha-se com isso. Nunca sofrer e nunca morrer. Ou seja, obter a imortalidade. É o que precisamente a técnica pretende poder dar ao homem.}

Como se precisasse ser encantados e reencantados por uma espécie de romance. Essa forma de narrativa varia conforme seja uma narrativa ideológica ou uma narrativa utópica. A ideologia está aí para justificar o existente, para esconder as contradições, as desigualdades e a exploração, e a utopia é outra coisa, que existe para motivar, mobilizar os espíritos e empurrá-los na direção de dias melhores. Tudo isso já tratei no meu livro, o Technique et idéologie, publicado em 2002 pela Seuil, que será traduzido em breve no Brasil. Nele apresento as marcas da utopia, que são 5: a primeira é o isolamento, em que a utopia se dá numa ilha; em segundo lugar, o dominio completo que o narrador tem sobre a narrati$v a$, quando conhece de tal maneira o assunto que conta algo incoerente, mas o leitor não percebe. O filósofo francês Louis Marin, que é especialista em utopias, tentou fazer um mapa a partir da utopia descrita pelo Thomas Morus, e não conseguiu, porque cada capítulo dizia respeito a um território e todas as partes eram incompatíveis entre elas. A terceira característica é a higiene, ca- 
racterizada pela transparência, visibilidade, como lugares onde se vê tudo ou então o desejo por conhecer tudo do seu corpo. A quarta é o Domínio da técnica, com a técnica sendo apresentada como solução para resolver todos os problemas: educação, saúde, tudo.

E a quinta característica é o Retorno à origem, que é fictício, como fizeram os jesuítas nas Missões, quando trocaram os nomes dos índios por nomes cristãos, proibiram as práticas sexuais dos índios ao relento, por considerá-las vergonhosas, ou quando destruíram as moradas para a construção de outro tipo de habitação, com formas européias. A idéia era dar ao índio a verdadeira origem, que era a cristã, como verdadeiros descendentes de Cristo. Todas estas características reunidas, somadas às da ideologia, dão ao homem um caráter extraordinário como se fosse Adão antes do pecado original.

LARANGEIRA - A utopia da técnica é dominar o ser humano?

SFEZ - Sim, e é uma visão totalitária querendo dominar o conjunto da totalidade dos corpos e dos espíritos. Nada escapa da influência da técnica, neste sentido. Pode-se perceber, por todas as características apresentadas, que é algo totalizante.

LARANGEIRA - Heidegger nos apresenta a técnica como ser. McLuhan mostrou a relevância da tecnologia no processo histórico. Virilio desvelou o homem protético. E surgiram os ciborgues, mutantes e corpos tecnologizados. $\mathrm{O}$ ser humano é, agora, a tecnologia de ponta da técnica?

SFEZ - Não entendi a questão.

LARANGEIRA - Com todas essas transformações, o homem tornou-se o maior exemplo da tecnologia de ponta da técnica?

SFEZ - Não acredito em nada disso. É tudo conversa fiada. Parece Virilio. Aliás, o Virilio não é antipático, não é responsável por ter dito isso. Na verdade, quem falou isso foi a Donna Haraway e outros que trabalham com o prefixo ciber. O Virilio só repetiu. A tecnologia não é nossa inimiga. Ela pode ajudar o homem a viver melhor, a sobreviver. Isso não vem de agora. Quando tomamos medicamento, é uma mistura da tecnologia química com a tecnologia humana. $\mathrm{O}$ transplante, por exemplo, é a mistura da tecnologia com o aspecto humano a serviço da humanidade. Diante das imbecilidades de uns e de outros, não acrescento nada. Nós não somos ciborgues.

LARANGEIRA - Por falar em ciborgues, a saúde perfeita é uma utópica pretensão humana ou um paradigma da obsessão da técnica?

SFEZ - Eis uma questão inteligente e muito melhor do que a anterior, porque em geral são as duas coisas. A tecnologia, sendo uma utopia, tem a pretensão de resolver todos os problemas do mundo, inclusive as questões da saúde. Desde o começo da humanidade sonha-se com isso. Nunca sofrer e nunca morrer. Ou seja, obter a imortalidade. É o que precisamente a técnica pretende poder dar ao homem. A conjugação destas duas vontades é que faz a grande força retórica da saúde perfeita, muito mais forte do que a retórica da comunicação. É de uma eficácia fabulosa. É onde a tecnologia tem a forma extraordinária. Agora, a expectativa média de vida na Europa, para os homens, é de 80 anos, e 84 para as mulheres. Não sei no Brasil. A comemoração dos 100 anos é cada vez maior. Isso tudo é o resultado da higiene, da melhor alimentação, progresso da química, dos medicamentos, das cirurgias, dos diagnósticos, progresso das máquinas de diagnosticar. Ninguém quer morrer. É neste sentido que a retórica da saúde perfeita acaba sendo eficaz, superior às da política e comunicação.

LARANGEIRA - A busca da saúde perfeita é equivalente à idéia da comunicação perfeita?

SFEZ - A busca da saúde perfeita é muito mais forte do que a busca da comunicação perfeita. Não há comparação entre as duas.

LARANGeira - Está no seu livro Crítica da Comunicação: O novo Cristo é a interação (1994, p. 276). Esta afirmativa estende-se ao jornalismo de fonte aberta, jornalismo participativo, jornalismo cidadão?

SFEZ - É muito importante saber o contexto da afirmação. Falei em relação às tecnologias do espírito. Neste aspecto, a interação, a interatividade, está lá no lugar do Cristo, para fazer a ligação entre o céu e a Terra.

LARANGEIRA - A interatividade teria o caráter profético, messiânico?

SFEZ - É preciso limpar a mente desta idéia. É preciso ver de onde vem esta idéia. É o argumento da venda dos computadores utilizado há 15 anos. Argumento engendrado por marqueteiros e publicitários. Para dizer que o computador facilitaria a conversa entre amigos, inventaram todo um circo, uma história de interatividade, e 15 anos depois se percebeu não ter nada de extraordinário, nenhum efeito social. Na França, Sarkozy foi combatido tanto pela mídia convencional quanto pelos blogs, que diziam horrores dele, e não deu em nada. Sarkozy foi eleito. $\mathrm{O}$ bom senso percebia que de um lado havia uma imbecil e do outro um senhor inteligente que poderia dirigir a França. E as pessoas escolheram. Os blogs não mudaram nada.

LARANGEIRA - Qual é o poder simbólico do campo da comunicação no imaginário da técnica?

SFEZ - É certo que teve uma eficácia e diz respeito a certos 
aspectos da utopia. A comunicação permite, por exemplo, acabar com o isolamento. Não é exatamente verdadeiro, mas permite sonhar um pouco. Exploraram muito bem isso no início. De um lado um homem, no meio um fio e na outra ponta uma mulher. Pretensamente, seria o fim do isolamento. Quanto ao completo domínio do narrador sobre a narrativa, já é mais duvidoso. Em relação ao retorno às origens, também é duvidoso que tenha alguma influência, salvo o que diz respeito à ecologia. Quando a gente combina ecologia e comunicação, como faz o Edgar Morin, aí aparecem possibilidades de modificação. Mas a condição é que se esteja saindo da comunicação e de misturar a comunicação com outra coisa. A idéia da transparência, visibilidade, clareza, vem acionada. Quanto à questão da técnica, a comunicação já pagou a sua dívida. Agora, quando se refere à saúde perfeita, aí o poder existe mesmo.

LARANGEIRA - Comunicar, em si, não quer dizer nada, é outra afirmativa sua (2007, p. 143). A comunicação, então, quer dizer alguma coisa?

SFEZ - É claro que sim. Só precisa refletir bastante. Não nos comunicamos tão facilmente entre eras culturais diferentes. Por exemplo, para se comunicar com um francês, não basta aprender o francês. É preciso conhecer os elementos internos, as pré-noções da cultura francesa. Depois de passar quatro meses no Brasil, sinto que posso me comunicar muito melhor com os brasileiros do que antes.

Agora conheço muito melhor as pré-noções da cultura brasileira. Percebi, por exemplo, com grande perplexidade depois de dois meses, que os estudantes não suportam críticas, e se eles não suportam é porque eles foram ensinados a não suportar. O que quer dizer que nós, professores, também não suportamos. Se critico de forma leviana, compreendo o aborrecimento dos estudantes. Mas se numa palestra ou exposição em sala de aula eu critico que uma colocação não tem sentido, que não corresponde ao assunto, estou ensinando os estudantes a pensar. Mas eles se recusam, não aceitam. Comunicar significa estar no mesmo registro, poder falar numa mesma linha de raciocínio. Quando estudantes franceses entram na universidade é para aprender a crítica. É verdade que estão se tornando cada vez mais ingênuos, mas no passado era assim: ensinar a criticar. Aprendi no Brasil algo muito profundo, nunca imaginado por mim: isso é comunicar. Não é simplesmente se servir do telefone ou computador.

LARANGEIRA - Para a comunicação se fazer compreendida ela precisa se livrar do tautismo no qual está envolta?

SFEZ - Ela realmente precisa se livrar deste tautismo, que é a sideração advinda da repetição. E como se livrar disto? Só pela crítica mankecos

\section{Principais obras do autor:}

Essai sur la contribution du doyen Hauriou au droit administratiffrançais. Paris: LGDJ, 1966.

Critique de la décision. Paris: FNSP, 1973.

L'enfer et le paradis - critique de la théologie politique. Paris: Press Universitaires de France, 1978.

La décision - Que sais je?. Paris: PUF, 1984.

La symbolique politique. Paris: PUF, 1988.

Critique de la communication. Paris: Seuil, 1988.

La politique symbolique. Paris: PUF, 1993.

Dictionnaire critique de la communication (org.). Paris: PUF, 1993, 2 vols.

La santé parfaite - critique d'une nouvelle utopie. Paris: Seuil, 1995.

La communication. $6^{a}$ ed. Paris: PUF, 2004 [1991].

Le rêve biotechnologique. Paris: PUF, 2001.

Technique et idéologie. Paris: Seuil, 2002.

\section{Obras traduzidas no Brasil:}

Crítica da comunicação. São Paulo: Loyola, 1994.

A saúde perfeita - crítica de uma nova utopia. São Paulo: Loyola, 1996

A comunicação. São Paulo: Martins Fontes, 2007. 